\title{
The role of spirituality in facilitating personal development according to the Pauline corpus
}

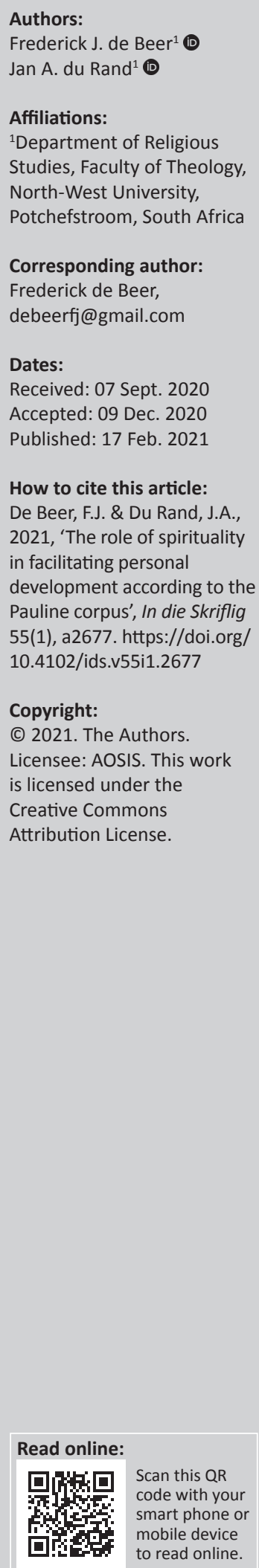

The concept of personal growth and development has been an ever-growing discipline in the last couple of decades, especially encapsulated by self-help constructs. The market for self-improvement literature, also known as self-help literature, is one of the fastest-growing fields over the last two decades. Spirituality has also become a prominent element in these popular self-help literatures. Interest in spirituality as a scholarly discipline, guided by academic disciplines, has grown in the last few decades, but so too has the interest in spirituality as a prominent component in popular texts such as self-help literature. Bible citations and concepts are frequently included in the theories on spirituality in these popular literature, but are not always interpreted within Christian constructs. The tendency to use Bible citations and concepts created the impression that spirituality in these self-help theories is a Christian precept. Spirituality, as a key factor in self-help literature, was examined in view of Christian Spirituality and biblical concepts. Transformation, experience, the body and the mind are central aspects of the spirituality advocated by these self-help literature. These central aspects were evaluated from a Pauline perspective and in view of Christian Spirituality with specific reference to Romans 8:1-30 and Romans 12:1-2. The specific reference to the Pauline corpus was motivated by the hypothesis that Christianity can historically claim intellectual property to the word spirituality, as the origins of the word can be attributed to Paul. Spirituality, in the quest for personal growth and development, implies the work of the Spirit in the life of the believer as a result of the Christ event. Christian Spirituality underlines the personal experience of the Spirit as evinced in the Pauline corpus. While spirituality is a scholarly discipline guided by academic disciplines, spirituality is also a key construct in popular self-help literature. The spirituality suggested in these self-help literature does not necessarily accord with biblical constructs. In Christian Spirituality, transformation is the consequence of the presence of the Spirit and not only by the mere implementation of so-called self-help methodologies or undefined spirituality.

Contribution: This article will assist the Christian believer who, in the quest for personal growth and development, engages spirituality with a biblical construct from a Pauline perspective and understanding of the role and work of the Spirit. While being aware of the fact that spirituality cannot be defined in restrictive terms, this article will nevertheless present some understanding of Christian Spirituality and the necessity of the Spirit as it relates to personal growth and development.

Keywords: spirituality; Christian Spirituality; self-help literature; personal growth and development; Spirit; transformation; mind; body; New Age spirituality; Paul.

\section{Introduction}

The market for self-improvement literature, also known as self-help literature, is one of the fastestgrowing fields over the last two decades. Self-help literature in the United States of America was worth $\$ 5.7$ billion in 2000 and grew more than $24 \%$ between 2003 and 2005. In recent years, the self-improvement market in the United States of America was worth \$9.38bn in 2016 and grew about $18 \%$ in 2 years to $\$ 11.0$ bn in 2018 . It was estimated in 2019 to grow $5 \%$ to reach $\$ 11.6$ bn with a further estimated growth projection of $4.8 \%$ per year on average from 2019 to 2023, when the market should be worth $\$ 13.9$ bn (LaRosa 2019; Marketdata Enterprises Incorporated 2008). A Gallop poll estimated that one-third to one-half of all Americans have purchased at least one 'self-help' book (Webb, Stetz \& Hedden 2008:703). As an untested hypothesis, this article will argue that the same tendency will emulate in South Africa. Various aspects influencing personal growth and development such as attitude, determination, emotional and psychological 
aspects are addressed by this literature. Spirituality ${ }^{1}$ features regularly as an integral constituent of personal growth and development, and spirituality has become an increasingly popular axiom in the secular society. Moberg (2010) noted the following:

The rising popularity of spirituality is accompanied by a flood of research in numerous disciplines to probe its relationships with health, wellness, and countless other topics. Initially subsumed under religion, especially Christianity, and still overlapping with it, spirituality is increasingly treated as a distinct topic that applies to all religions and to persons who have none with their diverse assumptions, variables, and terminology. Besides issues common to all social and behavioural sciences, spirituality research faces special challenges because of its subject matter. (p. 99)

While spirituality is a scholarly discipline guided by academic disciplines, spirituality is also a prominent constituent in popular texts such as self-help literature. This article will briefly examine spirituality as a constituent in self-help methodologies in view of the popularity of self-help literature as was pointed out. Christian Spirituality and Pauline theology with specific reference to Romans 8:1-30 and 12:1-2 will, however, be the primary focus in order to formulate a possible biblical construct, as it pertains to personal growth and development.

Experience and transformation, as integral constitutes in Christian Spirituality, will be construed as well as 'the body and mind', as it relates to Christian Spirituality. The body and mind are key aspects of personal growth and development in spirituality, but when interpreted in view of Christian Spirituality, it encounters a particular significance. This article will explore Paul's understanding of the body and mind, as they relate to the Spirit and salvation. The Spirit, salvation and the personal growth and development of the believer will be interpreted in view of Christian Spirituality. In Christian Spirituality, personal growth and development, in the aim of self-improvement, acknowledges human limitations and the necessity for the presence and working of the Spirit. When the believer explores spirituality as part of personal growth and development, it should always accord with biblical principles and the Christian message.

\section{The abstruseness of spirituality}

Spirituality is no longer understood as an exclusively Christian discipline, and contemporary tendencies include studying the relation between (1) spirituality and business, employment and management (Hense \& Maas 2011:77); (2) interpreting spirituality as it relates to the discipline of psychology (Loewenthal 2000:10; Paloutzian \& Park 2005:xi, 3); and (3) exploring the correlation between spirituality and mental health, well-being and psychopathology (Miller \& Kelley 2005:461, 467). Spirituality is now entrenched in every possible

1.Van der Merwe (2006:165) notes that a large number of academic and popular publications on the subject of spirituality has been published, and in a search on publications on the subject of spirtuality has been published, and in a search on following is found In the libre spithe in the libric in in the library of the University of Pretoria, 218 books, and in the library of Rhodes University, 263 books on spirituality as well as 7.5 million sites in an internet search on the search engine 'Google' containing the word spirituality. belief system and even in secular environments, which is evident from the observation made by Crisp (2009) that:

Health and welfare students may just as readily find that those who are teaching them about 'spirituality' would identify as being Buddhist, Jewish, Muslim, Wiccan, or from another traditional religion, new-age, or of no religion at all. (p. 7)

There is no longer a clear and unequivocal definition of the concept of spirituality that is acceptable to all. There is increasing confusion regarding the very meaning of spirituality as illustrated by the various interpretations of spirituality such as (1) individual self-realisation; (2) inwardness; (3) as a lifestyle with an emphasis on fitness and healthy living; (4) holistic well-being; and (5) selffulfilment and self-realisation. All of these resulted in spirituality eventually becoming a very broad and loose construct that is difficult to define (Kourie 2006:22; Louw 2010:69; Sheldrake 2007:2; Van Niekerk 2018:6). Spirituality in this popular self-help literature to some extend resonates with the so-called 'New Age spirituality'.

The tendency in New Age spirituality is to draw from the multiple religious traditions and combining it in an idiosyncratic code according to personal preferences. The New Age movement did not so much arise as a new religion, but as a new revivalist religious impulse directed toward the esoteric, metaphysical and mystical strain in all religions. These viewpoints accentuate transformation of the self through several activities, including channelling, communicating with and learning from the spirits of the dead, crystals, natural diets, astrology, bodywork, healing, and so forth (Aupers \& Houtman 2006:201; Mears \& Ellison 2000:291). New Age spirituality illustrates the tendency of individual bricolage - the construction of something by using a range of things that happen to be available and is therefore labelled as 'do-it-yourself-religion', 'pick-and-mix religion', 'religious consumption à la carte', or a 'spiritual supermarket' (Aupers \& Houtman 2006:201). These viewpoints are camouflaged with spiritual ambiguities, which can be misleading to the Christian believer, by creating a self-help mentality that negates the Spirit when evaluated against Christian Spirituality. Self-help literature that incorporates spirituality are rather inclusive of all the various concepts of divinity, and argues that various concepts of God are irrelevant as long as there is some spiritual alertness to a divine presence. New-age spirituality wants to distance it from mainline religion, or for that matter, Christianity, and sees itself as mainly non-religious. These movements reject any association with organised religion, and in particular Christianity. They argue that all religions share the same fundamental truths such as the awareness of spiritual essence (Aupers \& Houtman 2006:201; Heelas 2006:226; Prescott 2000:10). It is consequently common to find biblical references in self-help literature as well as references to God, Jesus and the Spirit, while even blending non-Christian writings with Christian concepts and biblical references (Aupers \& Houtman 2006:20; Prescott 2000:10; Temple-Thurston 2003:229). There are, however, no references to Christ or the Spirit as part of the process of redemption, transformation or restoration as God's ultimate destiny for humankind. 
Christ and the Spirit, as part of the process of redemption, transformation and restoration, are, however, foundational in Christian Spirituality. Spirituality in Christianity entails being transformed into a new creation through the working of the Holy Spirit, where the believer is conformed in the mystery of Christ's death and resurrection (Waaijman 2006b:47). When the believer is ignorant of the obscurities in the wider and broader spheres of non-Christian Spirituality, he or she may also be at risk of being deceived into a 'do-ityourself-religion', if the following statement by Dollar (2008) as a Christian pastor is any reflection thereof:

It amazes me to see the power of positive thinking operating in the lives of people who don't even know the Lord. They apply the principles of God's Word and get results. (p. 107)

Dollar views positive thinking as a biblical principle or a spiritual law and argues that it works regardless of any relationship with God. The danger of adapting spiritual laws that are contradictory to true Scriptural understanding of Christian doctrines, is also underlined by Maritz and Stoker (2016a:1-9) in their discourse of a series of sermons by At Boshoff, a pastor of a big Christian church, who proclaims the 'law of attraction' ${ }^{2}$ as a powerful principle in the Word of God. Boshoff argues that the 'law of attraction' is a 'central doctrine of Christianity based on the Bible', even though the term never occurs in the Bible and are subsequently connected to the modern New Age movement. The danger when believers do not decern that there are other influences and even 'spirits' also working within spirituality, may result in confusion and deception. Waaijman (2013:5) alludes to the fact that there is a field that regards the 'world of the spirits as an important field of experience'. This includes 'good spirits, evil spirits, angels and devils'. These so-called dark areas of spirituality also include themes such as channelling, near-death experiences, voices, visions and demons.

\section{Spirituality as a Christian attribute}

Spirituality encounters a more defined content within Christianity, and Christianity can historically claim 'intellectual property' to the word spirituality (Sheldrake 2007:2). While the word spirituality is a prevalent phrase today within all spheres, whether in religion or a secular environment, the origins of the word can be attributed to Paul. The word spirituality stems from the Latin word spiritualitas, which relates to the adjective spiritualis [spiritual]. The Latin formulation, however, comes from the Greek word $\pi v \varepsilon \tilde{\mu} \mu \alpha$ and the adjective $\pi v \varepsilon v \mu \alpha \tau$ ikó $\varsigma$ as found in Paul's letters. A person who is deemed spiritual, is essentially someone who lives under the influence of the Spirit with the Spirit dwelling in him or her (Lombaard 2019:2; Sheldrake 2007:2-4; Van Niekerk 2018:8). Scorgie (2011) also defines spirituality in view of its Christian origins when he says:

But spirituality began its semantic journey in the New Testament itself, where the apostle Paul used pneumatikoi (literally, spiritual person) to describe people who keep in step with the pneuma (Spirit) of God. (p. 27)

2. The basic claim of this spiritual "law" is that human beings create their own future through their thoughts and words' (Maritz \& Stoker 2016a:1).
Spirituality within Christianity refers to the foundational values, lifestyles and spiritual practices of believers, especially how it reflects their understanding of God, their human identity, and the material world as the context for human transformation (Sheldrake 2007:2). Spirituality nevertheless encompasses a variety of opinions within modern Christian perspectives, ranging from participation in organised religion to the participating in anything but organised religion (Burke 2005:42). Spirituality is also sometimes analysed and defined within organised religion according to theological orientations, such as (1) Pentecostal spirituality (Nel 2018:51); (2) Roman Catholic spirituality (Bregman 2004:158); (3) Reformed spirituality (Meiring 2018:2); or (4) Orthodox spirituality (Moberg 2010:110). Christian Spirituality outside organised religion is mainly defined as 'postmodern spirituality' (McKnight 2010:211), and while seeking spiritual pursuits and fulfilment, it views organised religion as manipulative, intolerant, judgemental and presumptuous (Burke 2005:90). There seems to be a blanket discrediting of organised religion as to not being spiritual or even being void of spirituality. This hypothesis needs to be revisited and argued, as spirituality is closely connected with religion while not exclusively contained by it (Van Niekerk 2018:10). In the same manner, the claim of exclusivity by some churches, when defining their specific expression of Christian worship as 'only them having spirituality' (Lombaard 2019:6), also warrants a critical evaluation. The literature on Christian Spirituality nevertheless agree on the foundational aspects of spirituality, namely the Christ event, the restorative, transformative and empowering aspect as well as the eschatological aspect of the Spirit (Archer 2005:2-13; Copan 2010:140-154; Stephenson 2006:83-105). Early writings of the Christian church reveal no distinction between spirituality and theology, and there was no distinct difference between Christian Spirituality, as the experience of God, and theology as the study and beliefs of God in Scripture (Coetzee \& Du Rand 2010:20; Hosmer 1984:425). Spiritual meaning of Scripture was as important as its literal and historical meaning, and was interpreted on different levels to convey a message that would guide, judge, illuminate understanding, and attempt fulfilment within a person (Scorgie 2011:27).

It is therefore necessary, in view of the open and broad interpretation of spirituality, to invite the Christian believer into Christian Spirituality. A singular definition of Christian Spirituality is nevertheless particularly difficult to conclude, and this point is shared by most scholars (Bregman 2004:158; LeRon Shults 2008:272; Meiring 2018:2; Moberg 2010:100; Pattison 2010:351). Loosely defined, Christian Spirituality is the interpretation and sustentation of the believer's experience of transformation in relation to God and other people, and the progressive accentuation of the connection between the Spirit and spirituality (LeRon Shults 2008:272). Meiring (2018:2) defines Christian Spirituality as 'a living relationship with God in Jesus Christ through the indwelling of the Holy Spirit, lived out in the community of believers and in the world'. The doctrine of the Spirit has been 
somewhat unconcerned with the practical implications and experiences of the Christian faith, but this tendency is being reconsidered by many in view of spirituality (LeRon Shults 2008:272) and rightly so, as spirituality is, in fact, an activity and not a mere cerebral thought system (De Villiers 2006:103). Christian Spirituality points to a relational process between God and man with a varying accent on the divine aspects of God, namely 'Awesome, the Holy, the Merciful, the Infinite One', and secondly, on the human aspect, namely 'application, dedication and awakening' (Waaijman 2006a:13). Scorgie (2011:28) offers a more compelling interpretation of Christian Spirituality in view of its origin in Paul's theology and against all the permutations of the concept of spirituality when he says: 'Christian Spirituality is ultimately about being attentive to the Holy Spirit's voice, open to his transforming impulses, and empowered by his indwelling presence. It is always Spirit-uality.'

Lombaard (2019:6), however, cautions against what he terms 'the conflation of understanding' when 'spirit' and 'spirituality' has as its main focus the third person in the Trinity. Lombaard (2019) argue that:

- Spirituality' is a multivalence term which can be indicated from academic considerations as much as from nonacademic writings of our time (with journalism serving as a productive example).

- The terms 'spirit', 'spirituality' and 'Holy Spirit' ought not to be conflated with one another either.

- Christian Spirituality studies the experience-expressiondynamics of the Christian faith, and not the Holy Spirit as a primary topic of investigation. (p. 7)

This is a valid argument by Lombaard, as spirituality, especially as an academic discipline, entails much more than what is comprehend within Christian Spirituality. Lombaard (2019) is correct when he states:

\footnotetext{
Caution is always required when dealing with such an open term in both popular usage and academic life. As a solution to the vagueness inherent in such an open term, defining 'spirituality' in restrictive terms would do justice neither to the phenomenon nor to the academic disciplines studying it. Hence, care must be exercised when the term 'spirituality' is encountered that it is to be engaged with both sympathetically and critically. (p. 7)
}

Nevertheless, for the sake of the intended argument, this article will contend that, in the endeavour to achieve personal growth or personal betterment of the body and mind, the Christian believer is in danger of descending to mere human effort in a self-help scheme when there is no reference to the work of the Holy Spirit.

\section{Experience and transformation as an integral constitute in Christian Spirituality}

Lombaard (2019:6) points out that, in the discipline of Christian Spirituality, the Holy Spirit is not the main focus but rather the 'experience-expression-dynamics of the
Christian faith', and in the wider discipline of spirituality, so too the study of the 'experience-expression-dynamics', as it 'relates to other religions and non-religious orientations of faith'. Although this is a very valid point, Christian Spirituality nevertheless underlines the personal experience of the Spirit. This experience by the believer results in a living faith, striving to discover the highest purpose by embracing the whole of life with Christian Spirituality, working itself out in all the many facets of life - even in caring for others (Dillen 2017:5; Hosmer 1984:425; Tolmie 2010:2-3; 2011:169, 174, 176).

While experience is argued by some as an integral aspect linked to spirituality, others question experience as a determining characteristic in spirituality by arguing that it may only centre on emotions, feelings or a set of behaviours. It is argued that, if spirituality is to be studied as an academic discipline, such a study can become entangled in a confusion of practical and philosophical problems. It is argued that spirituality must rather be interpreted in terms of the divinehuman relation and the process of transformation with an emphasis on the relational process and transformation, what rest on the truth found in the Scriptures (Frohlich 2001:65; Hemingway 2010:74; Tolmie 2010:4). Lombaard (2019:7) is, however, correct when he argues that, while the main focus in Christian Spirituality remains the 'experience-expressiondynamics of the Christian faith', it does not suggest a partial theology, as the Trinity is invariably part of the fundamental premises when studying spirituality. Experience can therefore not be discarded and needs to be appreciated in the understanding that Christian Spirituality can also be argued as an academic discipline. Nel (2018) rightly argues that:

Spirituality functions in a space wider than the intellectual, to include the whole of one's spiritual or religious experience, one's beliefs, convictions, and patterns of thought, one's emotions and behaviour in respect to what is ultimate, or God. (p. 5)

While Christian Spirituality is rooted in lived experience, it will encounter the difficulty and confusion associated with experience, and one must therefore strive to navigate Christian Spirituality intelligently in the complexity of life, as Christian Spirituality focuses on 'lived or experienced faith' and not on abstract theological or doctrinal issues (Frohlich 2001:65; De Villiers 2009:3).

Transformation is also a fundamental aspect linked to Christian Spirituality. The process of the divine-human relation is a gradual process of transformation and is coupled with the risen Christ. The presence of Christ in the life of believers empowers transformation and is the immediate intersection between the Spirit and the believer, which enables spiritual formation (De Villiers 2008:8; 2009:1; Waaijman 2006b:41). The significance of transformation in Christian Spirituality is pointed out by Waaijman (2006b) who says:

The word 'transformation' is part of a richly varied semantic field: to form, deform, reform, be conformed and transformed. Throughout the centuries spiritual authors have used this semantic field to bring out the inner logic of the spiritual way. 
For them this semantic field - and within it especially the term 'transformation' - refers to the most significant transitions in the divine-human relational process. (p. 41)

\section{Romans 8:1-30 and 12:1-2: The transformation of the body and mind by living in the Spirit}

Mind, body, spirit and transformation are prominent terms linked to concepts of spirituality within popular and 'newage' literature advocating personal growth and development. These beliefs at times argue their views by referring to the life and words of Jesus (Dyer 2001:43; Prescott 2000:10; Quinn 2004:41), but never in terms of the Christ event or the manifestation of the Spirit. The application of any principle or methodology to achieve personal growth or personal betterment of the body and mind with no reference to the work of the Holy Spirit, is in danger of descending to mere human effort in a self-help scheme. Such an advance denies the inability of humankind to redeem itself and that humankind was and is in need of a Saviour. It is therefore important that sound theology is applied when evaluating spirituality in these popular literatures. Theology is the mechanism to interpret and understand the experience from a confessional position, and must be understood as a tool to interpret rather than a mechanism used to prescribe. Theology and beliefs interact in view of self-understanding, revelatory characteristics, affirmations, symbols and practices with the intention to expand and interpret these in 'new historical contexts' (Villegas 2018:3-4).

Mind, body, spirit and transformation therefore encounters a rather specific meaning when used by Paul. Romans 8:1-30 and 12:1-2 are just two of the passages that underline Paul's understanding of the role of the Spirit in transformation. Formulating a hypothesis of the role of the Spirit in personal growth will necessarily encounter redemption as part of the process of transformation. The different viewpoints regarding the structure and exegesis of Romans 8:1-30 and 12:1-2 will not be considered, as this will not be the focus of this article. Nevertheless, when analysing Romans 12:1-2 and in particular Romans 8:1-30 in terms of Spirit, body and mind, it is noticeable that the work and the importance of the Spirit $(\pi v \varepsilon \tilde{v} \mu \alpha)$ is especially accentuated and is prevalent (Du Toit 2010:2). The role of the Spirit in transforming the body $(\sigma \tilde{\omega} \mu \alpha)$ is viewed in specific redemptive language, while the mind (voũs) is to be shaped and conformed by the Spirit.

An examination of Romans 8:1-30 and 12:1-2, as it relates to Spirit, mind and body, affirms the working of the Spirit pertaining to the believer's body and mind, and is delineated in Table 1.

When analysing Paul's theology, flesh ( $\sigma \alpha ́ \rho \xi)$ is understood as the corrupt constitutive of human existence, controlled by the law of sin, which needs to be replaced with the law of the Spirit and to be influenced by the manifestation of the Spirit $(\pi v \varepsilon \tilde{v} \mu \alpha \phi \alpha v \varepsilon \dot{\varepsilon} \rho \sigma 1 \varsigma)$ in order to effectuate the redemption of the body $(\sigma \tilde{\omega} \mu \alpha)$. The transformation $\left(\mu \varepsilon \tau \alpha \mu \rho \rho \varphi \omega^{\prime} \omega\right)$ of the believer into a different kind of bodily existence (Dunn 1998:61), is envisaged by Paul to be induced by the renewing

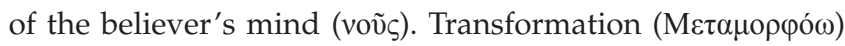
is, however, effectuated when the believer's moral mentality becomes transformed and the believer no longer thinks, understands and judges as he or she once did. The believer now minds the things of the Spirit, contrary to his or her previous behaviour, which was according to the flesh ( $\sigma \alpha \dot{\rho} \xi)$ (Lenski 1961:750). Paul also views the body $(\sigma \tilde{\omega} \mu \alpha)$, the flesh ( $\sigma \alpha ́ \rho \xi)$ and the mind (voũs) to influence the spiritual existence of the believer and are thus in need of redemption ( $\dot{\alpha} \pi \circ \lambda v i \rho \omega \sigma \iota)$. Within the Christian tradition, any betterment of a person is, however, mostly understood within the

TABLE 1: Analyses of Romans 8:1-30 and 12:1-2

\begin{tabular}{|c|c|c|}
\hline The Spirit & The body & The mind \\
\hline 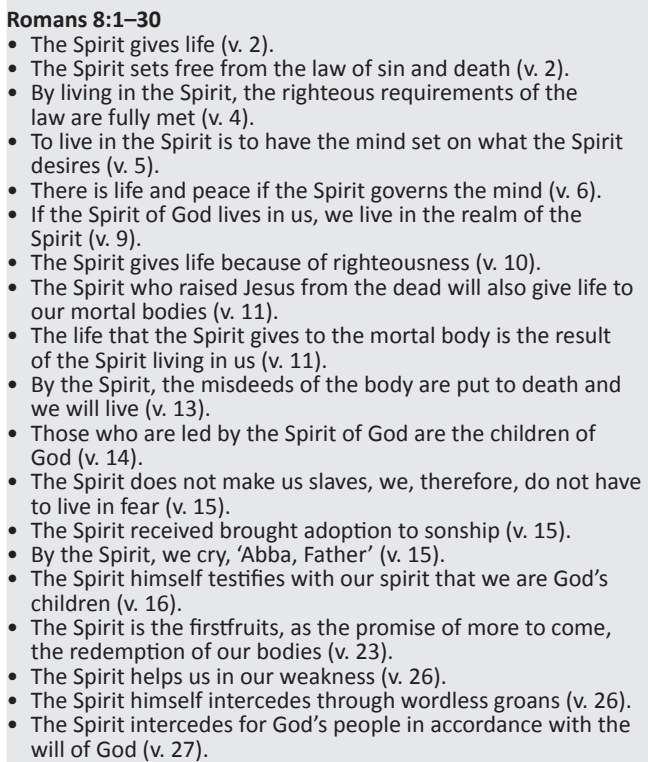 & $\begin{array}{l}\text { Romans 8:1-30 } \\
\text { - Has been free from the law of sin and death (v. 2). } \\
\text { - Ev not live according to the flesh (v. 4). } \\
\text { the Spirit gives life because of righteousness (v. 10). } \\
\text { - The Spirit will give life to mortal bodies because of the Spirit } \\
\text { who lives in us (v. } 11 \text { ). } \\
\text { - If by the Spirit we put to death the misdeeds of the body, we } \\
\text { will live (v. 13). } \\
\text { - Who have the firstfruits of the Spirit, groan inwardly, waiting } \\
\text { eagerly for adoption to sonship, the redemption of our bodies } \\
\text { (v. } 23 \text { ). } \\
\text { - Hope for what we do not yet have, waiting for it patiently } \\
\text { (v. } 25 \text { ). } \\
\text { - The Spirit helps us in our weakness (v. } 26 \text { ). } \\
\text { For those God foreknew he also predestined to be conformed } \\
\text { to the image of his Son, that he might be the firstborn among } \\
\text { many brothers and sisters (v. } 29 \text { ). Verse } 29 \text { would imply that it } \\
\text { is the whole person that must be conformed. While this does } \\
\text { not imply a physical body conformation, it would suggest that } \\
\text { our bodies will reflect the image of Christ as found in Romans } \\
12: 1 \text { where the body becomes a living sacrifice and part of } \\
\text { worship. } \\
\text { - Those he predestined, he also called; those he called, he also } \\
\text { justified; those he justified, he also glorified (v. } 30 \text { ). Verse } 30 \\
\text { would imply that the body, by being justified, is also glorified. } \\
\text { Romans } 12: 1-2: \\
\text { - The body is to be a living sacrifice, holy and pleasing to God. } \\
\text { - The result of when the body is a living sacrifice, holy and } \\
\text { pleasing to God is true and proper worship. }\end{array}$ & $\begin{array}{l}\text { Romans 8:1-30 } \\
\text { - Those who live in accordance with the } \\
\text { Spirit have their minds set on what the } \\
\text { Spirit desires (v. 5). } \\
\text { - The mind governed by the Spirit is life } \\
\text { and peace (v. 6). } \\
\text { - For those God foreknew he also } \\
\text { predestined to be conformed to the } \\
\text { image of his Son (v. 29). Verse } 29 \text { would } \\
\text { imply that it is whole person that must } \\
\text { be conformed. This would imply that } \\
\text { the mind must be conformed to reflect } \\
\text { the image of Christ. } \\
\text { Romans 12:1-2: } \\
\text { - The believer is to be transformed by the } \\
\text { renewing of the mind. } \\
\text { - When the mind is renewed it will then } \\
\text { be able to test and approve what } \\
\text { God's will is - his good, pleasing and } \\
\text { perfect will. }\end{array}$ \\
\hline
\end{tabular}


framework of the redemption ( $\dot{\alpha} \pi \mathrm{o} \lambda \hat{\tau} \tau \rho \omega \sigma 1 \varsigma)$ from sin and through the working of the Holy Spirit, which is a central theme in Paul's theology. Greef and Du Rand (2005) rightly notes:

For Paul, the work of the 'Holy Spirit' is evidenced in the certainty that the first part of the redemption of the whole person is 'realised' as the person of faith enters into the 'mode' of existence solely determined by the 'Spirit'. (p. 202)

Van der Westhuizen (2020:6) points out that the 'resurrection of the flesh is the continuity of life that has been brought into patterns of life' with the 'fleshly life resurrected' to be 'a life that has been brought to life by the Spirit through the discontinuity of death'. It is therefore imperative that personal growth and development, especially for the believer within a secular environment, be well defined. Coetzee and Du Rand (2010) correctly accentuates the transformational aspects of the Spirit in the life of the believer by saying:

Spirit-empowered, Spirit-discerned conformity to Christ is required (Rom. 12:1). It is however the Holy Spirit that brings about a Godward orientation of life, wherein the believer's relationship with God governs one's conduct, thinking, feeling and acting so that every aspect of human experience is transformed as it is integrated into a relationship with God. (p. 22)

The process of redemption has a specific end in mind; the entire transformation of the believer into the image of Christ. While Christian Spirituality is predominantly linked with the experience of the Spirit in a transformational manner and is always defined in view of the image of Christ, its manifestation must be reflected in every aspect of the believer's existence, namely spiritually, physically, psychologically and emotionally (Copan 2010:140; Hemingway 2010:74; LeRon Shults 2008:272; Walters 2010:32). The work of the Spirit will only be completed when the lost glory and disfigured image of God in the believer is wholly renewed. Waaijman (2006b) rightly defines this process as follows:

Reformation is aimed at the recovery of the original form of man, the image of God. To that end, it orients itself to a form which makes present the original figure. The reformation of the original image of God in man and conformation to the divine-human figure are extensions of each other. (p. 44)

The Spirit influences every aspect of human existence, denoting the power of the new life in a transformed and empowered human being (Nürnberger 2002:70). The Spirit is also the power to transform believers in their subsequent quest for growth and development. Believers were made in the image of God and are to relate to him in every aspect of their lives - not just with the spiritual part. Believers are to relate to God and express their likeness in all of life, namely in body, mind, emotions and will (Macaulay \& Barrs 1978:36). Pauline theology accentuates that human behaviour is influenced and shaped by the flesh, body and mind, and depending on its inclination, will gravitate towards the power that exhorts influence over it. If it is towards the sinful nature, flesh, body and mind will live or walk according to the flesh. If it is towards the Spirit, flesh, body and mind will live or walk according to the Spirit (Moo 2000:250). The body, flesh and mind are therefore deemed to have a substantial impact on human behaviour, particularly as it is viewed as the corruptible part of human existence. It is the Spirit that nevertheless transforms and this transformation correlates with the image of Christ and the Christ event. Van der Merwe (2018:6-7) rightly points out that it is the Spirit that inspires and enlightens the human understanding, gives life and guides in all truths, and empower believers' spiritually so that they can see, hear, interpret and experience God's daily involvement in their lives. Without the Spirit, Jesus would only be seen as a 'first-century rabbi' - a view that is prevalent in New Age and secular spirituality. Paul's theology thus argues specific views on the body, flesh and mind, particularly as it relates to the believer, and the subsequent influence of the Spirit and transformation is always in view of the image of Christ.

\section{Salvation as the causal construal in personal growth and development of the believer}

In the process of salvation and transformation in Christian Spirituality, the starting point for Paul was the obedience and response to what God had offered - something he recurrently brought to his readers' attention as a causal factor for their continuing spirituality. While non-Christian Spirituality and even religious tendencies intimate some recompense or the application of specific spiritual laws, Christian Spirituality underlines the acceptance of the role of the Spirit in the Christ event. No spiritual law or even 'the law' can substitute the working of the Spirit, as the law could not produce the saving faith, or help humanity to live up to what was expected. As the law was based on the endeavours and work of those who had to abide by it, Paul referred to it as 'works' of law and therefore equating it with works of the flesh (Loubser 2006:632). Christian Spirituality is, however, not the implementation of laws and suppositions in order to enter into some spiritual reality by means of a self-help methodology, but the realisation that God took the initiative and provided redemption and transformation through grace alone.

The overcoming of the sinful flesh becomes a feature in the ongoing process of salvation in that God's righteousness is not a once-off occurrence, but is sustained by God who is exerting continual justifying righteousness in view of the final judgement and exoneration, which will culminate in the final justification act at the end of time (Du Toit 2003:69). As the justified continue to sin, the process of salvation proceeds, as God persists with his justifying righteousness (Dunn 1998:385-388) as a phenomenon of two dimensions. In 'the process of salvation' (Gaffin 1998:585), there is firstly, the beginning, which is a definite happening at a specific point in time. Secondly, this redemption is not a consummated or completed work, but an ongoing reality, awaiting the final 
completion (Dunn 1998:465; Greef \& Du Rand 2005:198) and the believer has therefore 'not yet arrived, is not yet perfect and is always in via, in transit' (Dunn 1998:476). While Paul sees the actualisation of this ultimate goal in the resurrection of the body with the conflict between flesh, body, spirit and Spirit eventually ending in the apex of the restoration of God's image in the resurrected body (Dunn 1998:39, 80, 488), there is also the current universal predicament of humanity before God, and based on that, Paul exhorts the Romans to be transformed into the image of God (Walters 2010:38).

The believer can consequently experience the 'already' while longing for the 'not yet' as the result of what Jesus already did in the believer's life, while longing for the completion thereof. The 'now' and the 'new' (eschatological) is thus part of the believer's growth and development, and because Jesus is already present in the believer's world and existence through the Spirit, the 'new' which he will bring, is already visible in the 'now' (Greef \& Du Rand 2005:196). The redemption of the believer is not limited to only the 'soul', but the whole person, which therefore implies his or her temporal existence. The 'age to come' is already present, which implies that the believer can already celebrate and can now claim 'the new creation' by living in the power and working of the Spirit (Greef \& Du Rand 2005:197-198). The ongoing tension between the work began and the work not yet completed', is also the 'alreadynot yet' where the righteousness of God received, also becomes the righteousness of God that sustains the believer in view of the eschatological completion of the redemption. Without the ongoing sustainment by God, the work begun, will be in vain (Dunn 1998:476). The Spirit is the beginning of the redemption, but also the bridge between the present and the future restoration and transformation that still needs to be attained. This is all done by the Spirit who is playing a decisive part at the beginning of the redemption as well as the continued transformation and final redemption (Dunn 1998:470-476; Gaffin 1998:582; Pretorius 2006:261). Paul's theology sees redemption and salvation as the culmination or conclusion of a process with a decisive commencement, but it is also a lifelong process. Paul draws attention ( $\operatorname{Rm} 7: 24 ; 8: 23)$ to the continual tension between flesh, body and Spirit, which accompanies this process as an unavoidable reality (Dunn 1998:488-497). While Christian Spirituality entails the eschatological dimension, it is also rooted in the current bodily and temporal existence of the believer. This point is emphasised by De Villiers (2008) who says:

The ultimate transformation that awaits one at the end of the journey is translated into and must be viewed in the present. It is a journey in which believers experience an ongoing transformation amid suffering and temptation (1 Thess. 3:5). It means an inner transformation that has external consequences. It reflects increasing, overflowing love for God and others (1 Thess. 5:12). (p. 27)

When spirituality is employed in the betterment or transformation of someone, especially in the life of the
Christian believer and in view of Christian Spirituality, the words of Perrin (as cited in Lombaard 2019:7) are paramount: 'There is no Christian Spirituality without the Spirit - the Holy Spirit'.

\section{Conclusion}

Villegas (2018:5) sees spirituality as the study of 'lived experience' that engages the relevant questions about life, together with the beliefs and practices that are integrated into the believer's life. Villegas (2018) consequently argues:

Studies in Christian Spirituality could explore questions such as the following: How do persons formulate their quests for growth and greater wholeness? How do these questions and quests intersect with Christian beliefs? Which of these beliefs do persons appropriate to guide their lives? How are they actually interpreting these beliefs? In what ways have they found that Christian beliefs do not provide answers for their quests? (p. 5)

In the quest to answer these questions, especially in view of personal growth and betterment, it is imperative that Christian believers must understand their personal growth and development in view of Christian theology and biblical truths. The following can therefore be concluded: Firstly, the application of spirituality in the quest for personal growth and development implies the manifestation and work of the Spirit in the life of the believer as a result of the Christ event. Secular personal growth and development endeavours want to negate human weakness with various self-help methodologies and self-improvement emulations which are encapsulated with the ambience of spirituality. Dunn (1998:483), however, points out that it is precisely within the believer's weakness that the power of the Spirit manifests in order to facilitate redemption and transformation, which can be rendered as personal growth and development, but not by way of some self-help methodology. Humankind needed a Saviour, as it could not save or better itself and likewise; the believer needs the Spirit when engaging spirituality in the quest for personal growth and development contra to the patterns of the world and its self-help methodologies.

Secondly, the over emphasises of so-called 'spiritual laws' that suggest that humanity can create their own destiny, is in reality the dethronement of God and enthronement of humankind to where humans play the leading part and God is left only to meet all their needs and expectations (Maritz \& Stoker 2016b:5). Waaijman (2006b) rightly summarises the transformation process of the believer with the following:

Paul says: 'Do not follow the pattern of this world but be re-formed by the renewal of your mind' (Rom. 12:2). The 'divine passive' indicates that the reformation proceeds from God. Humans cooperate with this reformation: a continual renewal of the mindset whose purpose is to 'recognise what is the will of God - what is good and acceptable and perfect' (Rom. 12:2). The real reformation (metamorphosis) proceeds from God: the pattern (schèma) of the world must be abandoned; the form of God must again gain its grip on us. The spiritual writers continually thematise the field of tension: formation-reformation-transformation. (p. 44) 
Thirdly, within the Christian tradition, any perceived betterment of a person must be understood within the framework of the redemption from sin and the continued influence of the Spirit in the transformation of the believer, which is a central theme in Paul's theology. The term conversion can thus be used in the same nuances as transformation. Transformation is the result of the intersect with the Spirit that brings about such a deep change in the believer's relationship with God that it impacts his or her whole existence in such a way that it cascades into other dimensions of their life (Lombaard 2015:2). Christian Spirituality, when understood in light of the holistic approach to personal growth and development, suggests that the only way the human spirit, mind and body can be regenerated to a resolute existence and utilitarian significance, is when it has been redeemed and transformed by the Spirit in the Christ event. This is thus not only by the mere implementation of so-called self-help methodologies or undefined spirituality. Transformation, as one of the fundamental aspects of spirituality, is also one of the indispensable precepts in Christian Spirituality. Transformation, however, implies the meaningful and profound changes within people as they are touched by the Holy Spirit and as they mature in their experience of their faith (Lombaard 2015:1). While (Lombaard 2019:7) cautions against defining spirituality in restrictive terms, especially in view of the third person of the Trinity, in Christian Spirituality the emphasis on the working of the Spirit, as it pertains to personal growth and development in the pursuit of bettering oneself, remains part of the core assumption of Christianity.

\section{Acknowledgements Competing interests}

The authors have declared that no competing interest exist.

\section{Authors' contribution}

All authors contributed equally to this work.

\section{Ethical consideration}

This article followed all ethical standards for research.

\section{Funding information}

This research received no specific grant from any funding agency in the public, commercial or not-for-profit sectors.

\section{Data availability}

Data sharing is not applicable to this article as no new data were created or analysed in this study.

\section{Disclaimer}

The views and opinions expressed in this article are those of the authors and do not necessarily reflect the official policy or position of any affiliated agency of the authors.

\section{References}

Archer, K.J., 2005, 'The spirit and theological interpretation: A Pentecostal strategy', Journal for Pentecostal-Charismatic Research 16(1), 2-13.

Aupers, S. \& Houtman, D., 2006, 'Beyond the spiritual supermarket: The social and public significance of new age spirituality', Journal of Contemporary Religion 21(2), 201-222. https://doi.org/10.1080/13537900600655894

Bregman, L., 2004, 'Defining spirituality: Multiple uses and murky meanings of an incredibly popular term', The Journal of Pastoral Care \& Counseling 58(3), 157-167. https://doi.org/10.1177/154230500405800301

Burke, J., 2005, No perfect people allowed, Zondervan, Grand Rapids, MI.

Coetzee, A.M. \& Du Rand, J.A., 2010, 'A spirituality and "ethos of circumcision" for the contemporary church', Ekklesiastikos Pharos 92(1), 19-34.

Copan, V., 2010, 'Spiritual formation and St. Paul as spiritual director: Determining the primary aims', Journal of Spiritual Formation and Soul Care 3(2), 140-154. https:// doi.org/10.1177/193979091000300203

Crisp, B.R., 2009, 'Beyond the seminary: New frontiers for teaching spirituality', Religious Education 104(1), 4-17. https://doi.org/10.1080/00344080802615002

De Villiers, P.G.R., 2006, 'Spirituality, theology and the critical mind', Acta Theologica 27(2), 99-121. https://doi.org/10.4314/actat.v27i2.52319

De Villiers, P.G.R., 2008, 'The eschatology of 1 Thessalonians in the light of its spirituality', Acta Theologica 28(1), 1-32. https://doi.org/10.4314/actat.v28i1.48865

De Villiers, P.G.R., 2009, 'Peace in the Pauline letters: A perspective on biblical spirituality', Neotestamentica 43(1), 1-26.

Dillen, A., 2017, 'Beyond a sacrificial spirituality: Enhancing flourishing pastora ministers', HTS Teologiese Studies/Theological Studies 73(4), a4694. https://doi. org/10.4102/hts.v73i4.4694

Dollar, C.A., 2008, 8 steps to create the life you want, Faith Words Hachette Book Group, New York, NY.

Du Toit, A.B., 2003, 'Forensic metaphors in Romans and their soteriological significance', Verbum et Ecclesia 24(1), 53-79. https://doi.org/10.4102/ve.v24i1.311

Du Toit, A.B., 2010, 'Some more translation headaches in Romans', Verbum et Ecclesia 31(1), Art. \#385, 5 p. https://doi.org/10.4102/ve.v31i1.385

Dunn, J.D.G., 1998, The theology of Paul the Apostle, Wm. B. Eerdmans Publishing Company, Grand Rapids, MI.

Dyer, W.W., 2001, There is a spiritual solution to every problem, Thorsons, London.

Frohlich, M., 2001, 'Spiritual discipline, discipline of spirituality: Revisiting questions of definition and method', Spiritus 1(1), 65-78. https://doi.org/10.1353/scs. 2001.0009

Gaffin, Jr. R.B., 1998, “'Life-giving spirit”: Probing the center of Paul's pneumatology', Journal of the Evangelical Theological Society 41(4), 573-589.

Greef, G. \& Du Rand, J.A., 2005, 'The applicable personal role of the spirit in Pauline eschatology', Ekklesiastikos Pharos 87(16), 191-205.

Heelas, P., 2006, 'The infirmity debate: On the viability of new age spiritualities of life', Journal of Contemporary Religion 21(2), 223-240. https://doi.org/10.1080/ 13537900600656066

Hemingway, M.Z., 2010, 'Faith unbound. Why spirituality is sexy but religion is not', Christianity Today 54(9), 3-4.

Hense, E. \& Maas, F., 2011, 'Current perspectives on spirituality in northwestern Europe', Spiritus 11(1), 67-83. https://doi.org/10.1353/scs.2011.0014

Hosmer, R., 1984, 'Current literature in Christian spirituality', Anglican Theological Review 66(4), 423-441.

Kourie, C., 2006, 'The "turn" to spirituality', Acta Theologica 27(2), 19-38. https://doi. org/10.4314/actat.v27i2.52310

LaRosa, J., 2019, \$11 billion self-improvement market is growing in marketdata enterprises incorporated, viewed 06 May 2020, from https://www. marketdataenterprises.com/GeneralBusiness https://www.marketdataenterprises. com/category/general-business/

Lenski, R.C.H., 1961, The interpretation of St. Paul's Epistle to the Romans, Augsburg Publishing House, Minneapolis, MN

LeRon Shults, F., 2008, 'Spirit and spirituality: Philosophical trends in late modern pneumatology', Pneuma 30(1), 271-287. https://doi.org/10.1163/157007408X 346410

Loewenthal, K.M., 2000, The psychology of religion, Oneworld Publications, Oxford.

Lombaard, C., 2015, 'Biblical Spirituality and transformation', In die Skriflig / In Luce Verbi 49(2), Art. \#1950, 6 p. https://doi.org/10.4102/ids.v49i2.1950

Lombaard, C., 2019, 'First steps into the discipline: On the 'spirit' in the discipline of Christian spirituality', HTS Teologiese Studies/Theological Studies 75(1), a5456. https://doi.org/10.4102/hts.v75i1.5456

Loubser, G.M.H., 2006, 'The ethic of the free: A walk according to the spirit! A perspective from Galatians', Verbum et Ecclesia 27(2), 614-640. https://doi. org/10.4102/ve.v27i2.167

Louw, D.J., 2010, “Habitus" in soul care. Towards "spiritual fortigenetics" (parrhesia) in a pastoral anthropology', Acta Theologica 30(2), 67-88. https://doi.org/ 10.4314/actat.v30i2.67264

Macaulay, R. \& Barrs, J., 1978, Being human, the nature of spiritual experience, InterVarsity Press, Downers Grove, IL. 
Maritz, D.J. \& Stoker, H.G., 2016a, 'Does the Christian worldview provide a place for the law of attraction? (Part 1): An apologetic evaluation of the roots of this doctrine', Verbum et Ecclesia 37(1), a1571. https://doi.org/10.4102/ve.v37i1.1571

Maritz, D.J. \& Stoker, H.G., 2016b, 'Does the Christian worldview provide a place for the law of attraction? (Part 2): An apologetic evaluation of the way the Bible is used in promoting this idea', Verbum et Ecclesia 37(1), a1570. https://doi. org/10.4102/ve.v37i1.1570

Marketdata Enterprises Incorporated, 2008, U.S. market for self-improvemen products \& services, viewed 23 September 2011, from www.marketresearch. com/Marketdata-Enterprises-Inc-v416/Self-Improve

McKnight, S., 2010, 'Spirituality in a postmodern age', Stone-Campbell Journal 13(1), 211-224.

Mears, D.P. \& Ellison, C.G., 2000, 'Who buys new age materials? Exploring sociodemographic, religious, network, and contextual correlates of new age
consumption', Sociology of Religion 61(3), 289-313. https://doi.org/10.2307/ 3712580

Meiring, P., 2018, 'Reformed spirituality and the spirit of reconciliation: A personal journey', HTS Teologiese Studies/Theological Studies 74(4), a4934. https://doi. org/10.4102/hts.v74i4.4934

Miller, L. \& Kelley, B.S., 2005, 'Relationship of religiosity and spirituality with mental health and psychopathology', in R.F. Paloutzian \& C.L. Park (eds.), Handbook of the psychology of religion and spirituality, pp. 460-478, The Guilford Press, New York, NY.

Moberg, D.O., 2010, 'Spirituality research: Measuring the immeasurable?', Perspective on Science and Christian Faith 62(2), 99-114.

Moo, D.J., 2000, Romans, Zondervan, Grand Rapids, MI. (The NIV Application Commentary).

Nel, M., 2018, 'Pentecostal spirituality in dialogue with three early fathers of the eastern Orthodox tradition: A question of continuity', Journal of Early Christian History 8(2), 49-74. https://doi.org/10.1080/2222582X.2018.1454262

Nürnberger, K., 2002, 'The spirit of god: A soteriological metaphor in biblical history and its significance for us today', Scriptura 79(1), 55-80. https://doi. org/10.7833/79-0-773

Paloutzian, R.F. \& Park, C.L., 2005, 'Integrative themes in the current science of the psychology of religion', in R.F. Paloutzian \& C.L. Park (eds.), Handbook of the psychology of religion and spirituality, pp. 3-20, The Guilford Press, New York, NY.

Pattison, S., 2010, 'Spirituality and spiritual care made simple: A suggestive, normative and essentialist approach', Practical Theology 3(3), 351-366. https://doi. org/10.1558/prth.v3i3.351

Prescott, S., 2000, Realizing the self within, Kima Global Publishers, Rondebosch.

Pretorius, M., 2006, 'The theological centre of Pauline Theology as it relates to the holy spirit', HTS Teologiese Studies/Theological Studies 62(1), 253-262. https:// doi.org/10.4102/hts.v62i1.354
Quinn, G., 2004, Living in the spiritual zone, Hodder \& Stoughton Ltd, London.

Scorgie, G.G., 2011, 'Overview of Christian spirituality', in G.G. Scorgie, S. Chan, G.T. Smith \& J.D. Smith III (eds.), Dictionary of Christian spirituality, pp. 27-33, Zondervan, $\mathrm{Ml}$.

Sheldrake, P.F., 2007, A brief history of spirituality, Blackwell Publishing Ltd, Oxford.

Stephenson, C.A., 2006, 'The rule of spirituality and the rule of doctrine: A necessary relationship in theological method', Journal of Pentecostal Theology 15(1), 83-105. https://doi.org/10.1177/0966736906069258

Temple-Thurston, L., 2003, The marriage of spirit, CoreLight Publishing, Santa Fe, NM.

Tolmie, D.F., 2010, 'Spirituality in Galatians', Bible and Spirituality Symposium, Glenfall House, Cheltenham.

Tolmie, D.F., 2011, 'The spirituality of the Letter to the Galatians', Acta Theologica 31(suppl. 15), 167-182. https://doi.org/10.4314/actat.v31i1S.10

Van der Merwe, D.G., 2006, "Having fellowship with God" According to 1 John: Dealing with the intermediation and environment through which and in which it is constituted', Acta Theologica 27(2), 165-192. https://doi.org/10.4314/actat. v27i 2.52325

Van der Merwe, D.G., 2018, 'Prayer, the encounter and participation, the experience: A Pauline exhortation towards a spirituality of prayer', Verbum et Ecclesia 39(1), a1768. https://doi.org/10.4102/ve.v39i1.1768

Van der Westhuizen, H., 2020, 'The spirit and salvation?', In die Skriflig/In Luce Verbi 54(1), a2537. https://doi.org/10.4102/ids.v54i1.2537

Van Niekerk, B., 2018, 'Religion and spirituality: What are the fundamental differences?', HTS Teologiese Studies/Theological Studies 74(3), a4933. https:// doi.org/10.4102/hts.v74i3.4933

Villegas, D.L., 2018, 'Spirituality and belief: Implications for study and practice of Christian spirituality', HTS Teologiese Studies/Theological Studies 74(3), 5037. https://doi.org/10.4102/hts.v74i3.5037

Waaijman, K., 2006a, 'What is spirituality?', Acta Theologica 27(suppl. 8), 1-18.

Waaijman, K., 2006b, 'Conformity in Christ', Acta Theologica 27(suppl. 8), 41-53.

Waaijman, K., 2013, 'Discernment and biblical spirituality: An overview and evaluation of recent research', Acta Theologica 33(suppl. 17), 1-12. https://doi.org/10.4314/ actat.v32i2S.1

Walters, J.E., 2010, 'How beautiful are my feet: The structure and function of second Isaiah references in Paul's Letter to the Romans', Restoration Quarterly 52(1), 29-39.

Webb, M., Stetz, K. \& Hedden, K., 2008, 'Mental illness in Christian bestsellers', Mental Health, Religion \& Culture 11(7), 697-717. https://doi.org/10.1080/13674670 801978634 